\title{
Investigation of sustainable porous carbon as radar absorbing material
}

\author{
Alan Fernando Ney Boss ${ }^{1}$, Helena Ravaglia Ferreira ${ }^{2}$, \\ Flavia Lega Braghiroli ${ }^{3}$, Gisele Aparecida Amaral-Labat ${ }^{4}$, \\ Ariane Aparecida Teixeira de Souza ${ }^{4}$, Hassine Bouafif ${ }^{3}$, \\ Ahmed Koubaa ${ }^{5}$, Mauricio Ribeiro Baldan ${ }^{4}$, \\ Guilherme Frederico Bernardo Lenz e Silva ${ }^{1}$
}

\footnotetext{
${ }^{1}$ Universidade de São Paulo - Escola Politécnica, Departamento de Engenharia Metalúrgica e de Materiais, Av. Professor Mello Moraes, 2463, CEP: 05508-030, São Paulo, SP, Brazil.

${ }^{2}$ Instituto Federal de São Paulo, Departamento de Química, Rodovia Presidente Dutra, km 145, s/n, CEP: 12223-201. São José dos Campos, SP, Brazil.

${ }^{3}$ Centre technologique des résidus industriels (CTRI), Laboratoire de biomasse, bioénergie et bioproduits, Boulevard du Collège, 433, J9X 0E1, Rouyn-Noranda, Québec, Canada.

${ }^{4}$ Instituto Nacional de Pesquisas Espaciais, Laboratório Associado de Sensores e Materiais, Av. dos Astronautas, 1758, CEP: 12227-010, São José dos Campos, SP, Brazil.

${ }^{5}$ Université du Québec en Abitibi-Témiscamingue (UQAT), L'Institut de recherche sur les forêts (IRF), Boulevard de l'Université, 445, J9X 5E4, Rouyn-Noranda, Québec, Canada.

e-mail: alan.boss@usp.br, guilhermelenz@usp.br,hravaglia@gmail.com, flavia.braghiroli@ cegepat.qc.ca, hassine.bouafif@cegepat.qc.ca, gisele.amarallabat@gmail.com, ariane_apts@hotmail.com, mauricio.baldan@inpe.br, ahmed.koubaa@uqat.ca
}

\begin{abstract}
Radar Absorbing Materials (RAMs) are composite materials able to attenuate an incident electromagnetic wave. Usually, RAMs are made of a polymeric matrix and an electromagnetic absorbent filler, such as silicon carbide or carbon black. Several materials have been investigated as potential fillers, aiming to improve the Reflection Loss (RL) and absorption bandwidth broadening. In this paper, a composite made with silicone rubber and biochar was investigated as a sustainable porous carbon made with biomass waste. Five different composites were characterized, composed of $1-5 \mathrm{wt} . \%$ of biochar in the silicone rubber. Although the RL of pure biochar composites is not significant, it was demonstrated here how a biochar composite can improve the RL of a RAM material when it is applied as a double-layer structure. While the RL of a ferrite-based RAM with $2.0 \mathrm{~mm}$ thickness reaches $-28 \mathrm{~dB}$, a combination of this RAM with biochar composite reaches $\sim-60 \mathrm{~dB}$ with the same thickness. The double-layer structure with $2.3 \mathrm{~mm}$ thickness can have an absorption bandwidth of $2.95 \mathrm{GHz}$ over the X-band frequency range, and a structure with $2.6 \mathrm{~mm}$ thickness can reach a RL of -76 dB. This demonstrates a sustainable, cheaper, and lighter material application (i.e., biochar), which is successfully used in the development of high-efficient electromagnetic shield or sensors.
\end{abstract}

Keywords: Biochar, permittivity, RAM, sustainability, reflectivity.

\section{INTRODUCTION}

Radar Absorbing Materials (RAMs) are composite materials made of a polymeric matrix and a lossy dielectric/magnetic material. Usually, lossy magnetic materials such as ferrites are preferable as fillers, but dielectric materials have been used as well [1]. RAM is commonly used in stealth technology, attenuating the incident electromagnetic wave from radars [2], but other applications like radomes [3], electromagnetic shielding [4], and sensors [5] have been recently considered.

RAM can work in two different ways. It can admit the signal and reduce its intensity internally when there is an impedance matching, i.e., the intrinsic impedance of the material is close to the air impedance, or it can create internal reflections hindering the reflected signal by the air-material interface. Both approaches depend on the material thickness and properties, and in some cases, a broadband RAM is made of several 
layers of different materials [6]. Examples of materials used as fillers in RAM are nickel-zinc ferrite [7], carbonyl iron [8], silicon carbide [9], and carbon materials like carbon black [10], graphene [11] or carbon nanotube [12]. An excellent RAM should be able to attenuate more than $99.9 \%$ of the incident wave, i.e., it should reach at least $-30 \mathrm{~dB}$ (see Table 1). It is also desirable a large Absorption Bandwidth (ABW), which is estimated by the frequency range where the RL is below $-10 \mathrm{~dB}[13]$.

Table 1: Relation between RL and percentage of electromagnetic wave absorption

\begin{tabular}{l|l}
\hline ATTENUATION $(\mathrm{dB})$ & INCIDENT WAVE ABSORPTION $(\%)$ \\
\hline 0 & 0.00 \\
\hline-3 & 50.00 \\
\hline-10 & 90.00 \\
\hline-15 & 96.90 \\
\hline-20 & 99.00 \\
\hline-30 & 99.90 \\
\hline-40 & 99.99 \\
\hline
\end{tabular}

Although carbon materials have been used as RAM, sustainable carbon materials are still poorly documented. In the present study, biochar is investigated as a potential sustainable filler. Biochar is a porous carbon material obtained from the thermochemical transformation of biomass waste, such as agricultural wastes, municipal sewage sludge, wood residues, among others $[14,15]$. Biochar may present an internal honeycomb structure [16], and can find applications on soil amendments, adsorbent for soil and water, catalysts, component for fuel cell systems, gas storage media, supercapacitors, batteries, and so on [17]. Also, finding new uses for waste materials meets the directives of sustainable development described in the Brundtland report [18], which encourages reducing the abusive consumption of raw material to slow down deforestation and global warming.

\section{MATERIALS AND METHODS}

Different RAM materials made of silicone rubber and biochar were evaluated over the X-band frequency range $(8.2-12.4 \mathrm{GHz})$. The complex permittivity and reflection loss of each sample is evaluated to demonstrate how RAM made with biochars can be effective on a multilayer composite structure.

\subsection{Materials}

Composite samples were prepared using commercial silicone rubber and biochar. Samples were composed of biochar mass proportions of 1, 2, 3, 4 and $5 \mathrm{wt} . \%$.

Biochar was produced from white birch residues coming from sawmills from the AbitibiTémiscamingue region, Québec, Canada. Wood residues were first converted into biochar through a CarbonFX technology (Airex Energy, Bécancour, Québec) and then, chemically activated in a prototype activation furnace in presence of $\mathrm{KOH}$ at $900^{\circ} \mathrm{C}$. More details about the biochar production can be found in Refs. $[17,19]$. For this specific application, the modified biochar is interesting because of its natural honeycomb structure [20], which is a common characteristic of materials prepared from cellulosic biomass.

Composite samples were prepared to fit the X-band rectangular waveguide. The dimensions of the samples were $22.86 \times 10.16 \times 2.00 \mathrm{~mm}$.

\subsection{Methods}

RAM samples were electromagnetically characterized using a Vector Network Analyzer (VNA). Through the S-parameters provided by the VNA, it was possible to calculate the permittivity using the Nicolson-Ross Weir (NRW) algorithm [21, 22].

The reflection loss (RL) can be calculated using [23, 24]:

$$
R L=20 \log \left|\frac{Z_{\text {in }}-Z_{0}}{Z_{\text {in }}+Z_{0}}\right|
$$




$$
Z_{\text {in }}=Z_{0} \sqrt{\frac{\mu_{r}}{\varepsilon_{r}}} \tanh \left(j\left(\frac{2 \pi f d}{c}\right) \sqrt{\mu_{r} \varepsilon_{r}}\right)
$$

where $Z_{0}$ is the free space impedance, $Z_{i n}$ is the impedance between free space and material interface, $\mu_{r}$ is the complex permeability, $\varepsilon_{r}$ is the complex permittivity, $f$ is the frequency, $d$ is the thickness, and $c$ is the speed of light. The RL can also be measured through VNA with a metallic plate behind the sample [25].

Likewise, the RL of a double-layer structure (Figure 1) can be calculated through a similar equation, but the impedance between material interface and free space $\left(Z_{\text {in }}\right)$ is given by [26]:

$$
\begin{aligned}
& Z_{\text {in }}=Z_{2} \frac{Z_{\text {in } 1}+Z_{2} \tanh \left[j\left(\frac{2 \pi f d_{2}}{c}\right) \sqrt{\mu_{2} \varepsilon_{2}}\right]}{Z_{2}+Z_{\text {in } 1} \tanh \left[j\left(\frac{2 \pi f d_{2}}{c}\right) \sqrt{\mu_{2} \varepsilon_{2}}\right]} \\
& Z_{\text {in } 1}=Z_{1} \tanh \left[j\left(\frac{2 \pi f d_{1}}{c}\right) \sqrt{\mu_{1} \varepsilon_{1}}\right]
\end{aligned}
$$

where $Z_{\text {inl }}$ is the impedance between the first and second layer, $Z_{1}$ is the first layer impedance, $Z_{2}$ is the second layer impedance and $d_{1}, d_{2}, \mu_{1}, \mu_{2}, \varepsilon_{1}$ and $\varepsilon_{2}$ are, respectively, the thickness, the complex permeability and the complex permittivity of each layer.

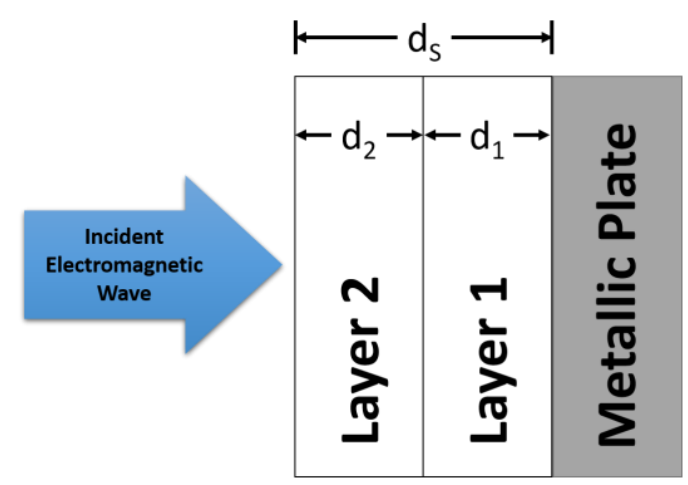

Figure 1: Illustration of a double-layer structure.

\section{RESULTS}

The characteristic tubes (Figure 2) of the honeycomb structure are responsible for acquiring nutrients from the soil and making them available for the plants remains flawless even after the thermochemical transformation of the wood residues. This helps to keep the material as a lightweight structure.

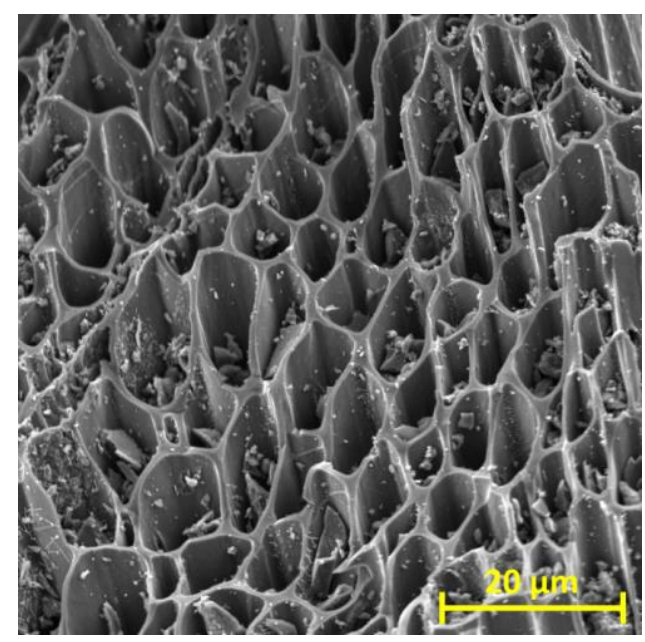

Figure 2: Scanning Electron Microscopy (SEM) of white birch biochar flake. 
The permittivity of each biochar sample over the X-band frequency range is presented in Figure $3 \mathrm{a}$. It was noticed that the real permittivity ( $\left.\varepsilon^{\prime}\right)$ increases with the increasing amount of biochar in the composite. The sample with $5 \mathrm{wt} . \%$ reached a saturation state, while the sample with $4 \mathrm{wt} . \%$ resulted in the same permittivity value, which is about $\varepsilon^{\prime}=4.2$ over the entire frequency range. The imaginary permittivity ( $\left.\varepsilon^{\prime \prime}\right)$ for all samples is extremely low. Even the sample with $5 \mathrm{wt} . \%$ presented values of $\varepsilon$ " below 0.20 . It can be seen in Figure $3 \mathrm{~b}$ that the measured RL of all samples is close to $0 \mathrm{~dB}$, indicating that the incident wave is being completely reflected. This happens because the composites are lossless materials, i.e., the amount of biochar used in the silicone rubber was not enough to create a conductivity, neither a strong reflection in the airmaterial interface.

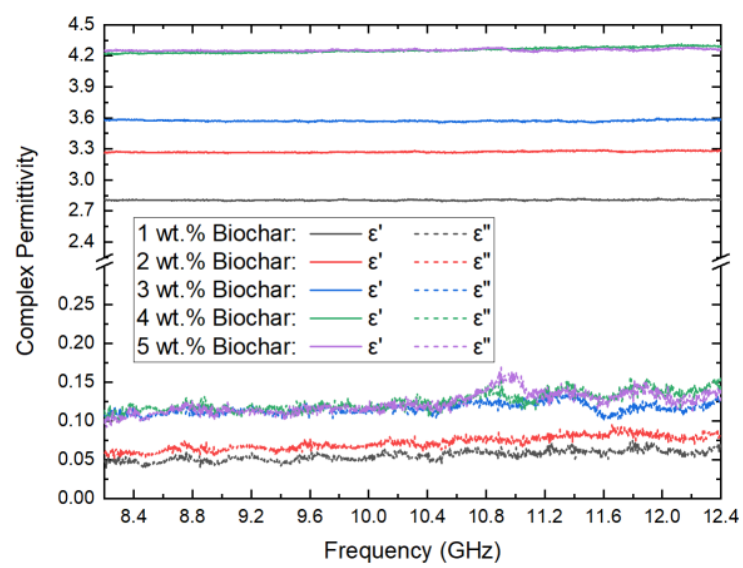

(a)

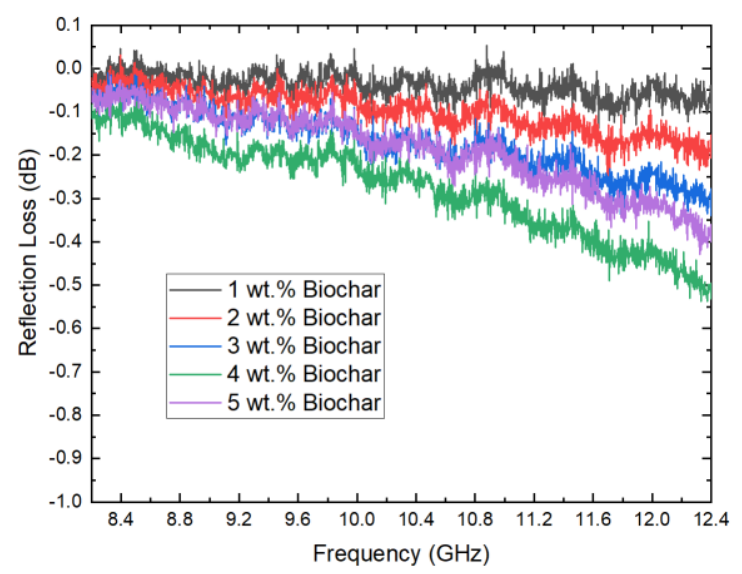

(b)

Figure 3: (a) Real ( $\left.\varepsilon^{\prime}\right)$ and imaginary ( $\left.\varepsilon^{\prime \prime}\right)$ parts of the complex permittivity and (b) measured reflection loss of composite samples with $1,2,3,4$ and 5 wt. $\%$ biochar.

\section{DISCUSSION}

Biochar composites presented no significant RL when experimentally analyzed. As a matter of fact, the composite made with 4 wt.\% biochar is not an appropriate absorber in any thickness, as seen in Figure 4a, where the RL is plotted as a function of frequency and thickness. However, considering a ferrite-based composite from the literature (50 wt.\% of NiFe ferrite and 1 wt. $\%$ of CNT) [27] with $\varepsilon^{\prime}=12.5, \varepsilon "=2.5, \mu{ }^{\prime}=1.2, \mu^{\prime \prime}=0.3$ over the entire frequency range, the calculated RL would reach about $-28 \mathrm{~dB}$ between thicknesses $1.6-$ $2.3 \mathrm{~mm}$ (Figure 4b). In this case, the larger absorption frequency range would be for sample with $2.0 \mathrm{~mm}$ thickness, where it ranges from $8.24 \mathrm{GHz}$ to $11.16 \mathrm{GHz}$, totalizing an absorption bandwidth of $\mathrm{ABW}=2.92 \mathrm{GHz}$.

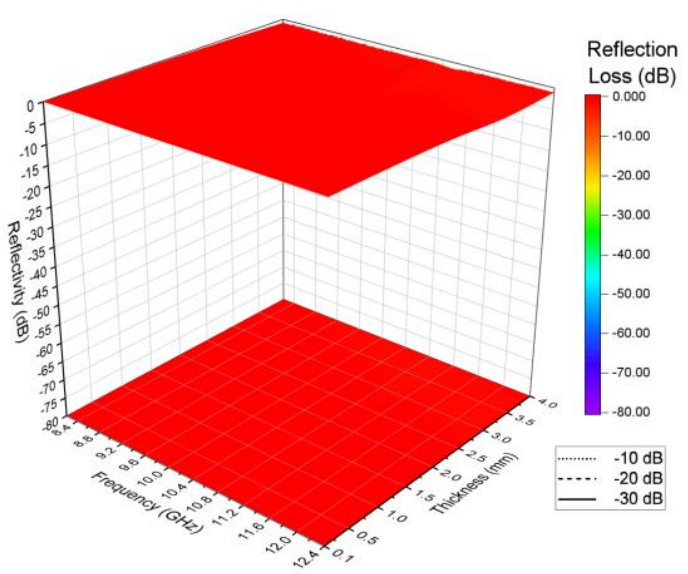

(a)

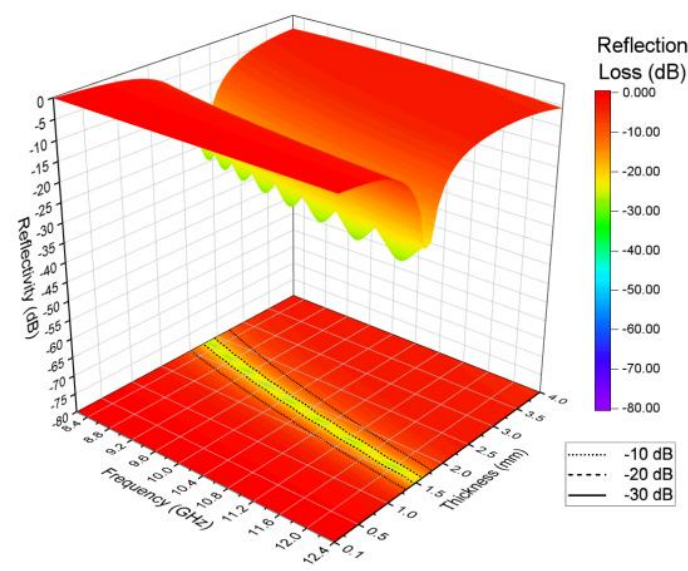

(b)

Figure 4: 3D RL of the composite made with (a) 4 wt.\% biochar and (b) the ferrite-based composite. 
When these materials are combined in a double-layer structure, a significant RL improvement can be noticed. This improvement can be seen in Figure 5, where different thicknesses for double-layer structures are presented. In this analysis, layer 1 is the $4 \mathrm{wt} . \%$ biochar, and layer 2 is the ferrite-based composite. Each graph represents a different thickness of the structure, given by $d_{S}=d_{1}+d_{2}$. The thickness axis in the $3 D$ plot represents only the thickness of the second layer $\left(\mathrm{d}_{2}\right)$. A structure with $1.6 \mathrm{~mm}$ thickness, where layer 1 is $0.2 \mathrm{~mm}$ and layer 2 is $1.4 \mathrm{~mm}$, reaches a RL of $-39.09 \mathrm{~dB}$ at $12.32 \mathrm{GHz}$ (Figure $5 \mathrm{a}$ ). The absorption frequency range goes from $10.68 \mathrm{GHz}$ to the next band, i.e., $\mathrm{K}_{\mathrm{u}}$-band. Figure $5 \mathrm{~b}$ is the RL of a structure with a total thickness equals to $2 \mathrm{~mm}$, with $\mathrm{d}_{1}=0.2 \mathrm{~mm}$ and $\mathrm{d}_{2}=1.8 \mathrm{~mm}$. The RL reaches $-56.89 \mathrm{~dB}$ at $9.80 \mathrm{GHz}$, and the absorption frequency range falls between $8.47-11.34 \mathrm{GHz}$, resulting in an $\mathrm{ABW}$ of $2.87 \mathrm{GHz}$. For a structure with $\mathrm{d}_{\mathrm{S}}=2.3 \mathrm{~mm}$ thickness, where $\mathrm{d}_{1}=0.2 \mathrm{~mm}$ and $\mathrm{d}_{2}=2.1 \mathrm{~mm}$, the RL is $-57.09 \mathrm{~dB} @ 8.49 \mathrm{GHz}$ (Figure $5 \mathrm{c}$ ). The absorption frequency range starts in the previous band (C-band) and goes up to $9.84 \mathrm{GHz}$. A thicker structure with $\mathrm{d}=2.6 \mathrm{~mm}$ has no significant absorption peak in the X-band, and its absorption bandwidth is $0.58 \mathrm{GHz}$ (Figure 5d). Probably, the main peak is in the C-band, and the ABW spreads to the X-band. When the ferrite-based composite is considered as the second layer, the multilayer structure works as a graded Dallenbach layer [28], where the second reflection caused by the metallic plate has the same amplitude that the first reflection caused by the air-material interface, but the opposite phase hinders the signal.

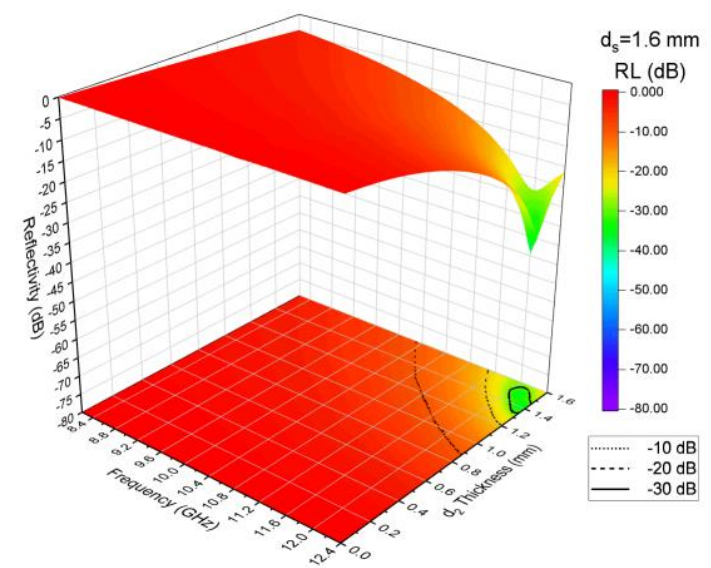

(a)

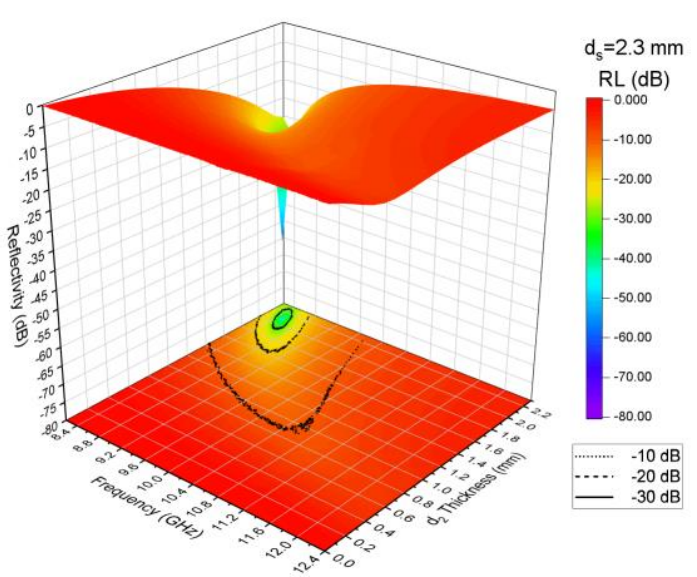

(c)

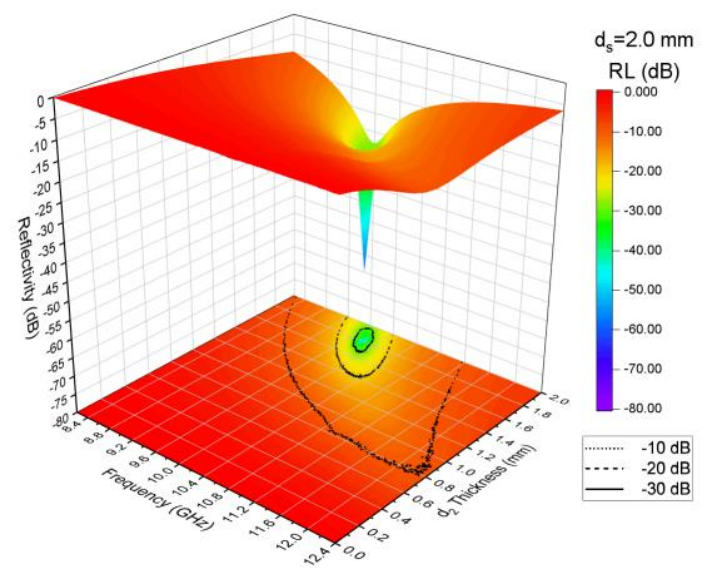

(b)

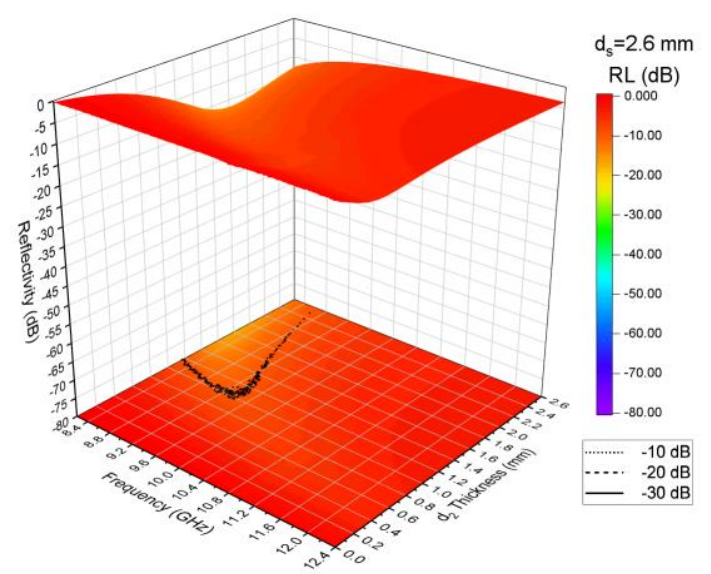

(d)

Figure 5: RL of multilayer system where the first layer is the 4 wt.\% biochar composite and the second layer is a ferrite-based composite. The total thicknesses of the double-layer structures are (a) $1.6 \mathrm{~mm}$ (b) $2.0 \mathrm{~mm}$, (c) $2.3 \mathrm{~mm}$ and (d) $2.6 \mathrm{~mm}$.

The same analysis is made with both materials in different positions, i.e., the ferrite-based composite is now layer 1 and the $4 \mathrm{wt} . \%$ biochar composite is layer 2 . For a total thickness of $1.6 \mathrm{~mm}$, with $\mathrm{d}_{1}=1.5 \mathrm{~mm}$ and $\mathrm{d}_{2}=0.1 \mathrm{~mm}$, the best RL is $-27.62 \mathrm{~dB}$ at $12.40 \mathrm{GHz}$ (Figure $6 \mathrm{a}$ ). This is almost the same RL for the ferrite-based RAM with the same thickness. The ABW is $1.60 \mathrm{GHz}$, which is smaller than the RAM bandwidth of $2.09 \mathrm{GHz}$. However, the double-layer structure best RL is in the X-band highest frequency, indicating that $\mathrm{RL}$ and $\mathrm{ABW}$ can be better if the $\mathrm{K}_{\mathrm{u}}$ frequency band is considered in this analysis. Figure $6 \mathrm{~b}$ presents a sig- 
nificant improvement of the RL, reaching $-44.93 \mathrm{~dB}$ at $11.68 \mathrm{GHz}$ with a structure having a total thickness of $2.0 \mathrm{~mm}$. In this case, layer 1 has $1.5 \mathrm{~mm}$ and layer 2 has $0.5 \mathrm{~mm}$. The absorption frequency range starts at $10.09 \mathrm{GHz}$ and goes beyond the X-band limit of $12.40 \mathrm{GHz}$. A sample with $\mathrm{d}_{\mathrm{S}}=2.3 \mathrm{~mm}, \mathrm{~d}_{1}=1.8 \mathrm{~mm}$ and $\mathrm{d}_{2}=0.5 \mathrm{~mm}$ has a RL of $-49.92 \mathrm{~dB} @ 9.89 \mathrm{GHz}$ (Figure $6 \mathrm{c}$ ). It has the biggest absorption bandwidth observed among all others, $2.95 \mathrm{GHz}$, ranging from $8.53 \mathrm{GHz}$ to $11.48 \mathrm{GHz}$. Lastly, the structure with $\mathrm{d}_{\mathrm{S}}=2.6 \mathrm{~mm}$, $\mathrm{d}_{1}=2.0 \mathrm{~mm}$ and $\mathrm{d}_{2}=0.6 \mathrm{~mm}$ has the best RL calculated: $-76.56 \mathrm{~dB}$ at $8.85 \mathrm{GHz}$ (Figure $6 \mathrm{~d}$ ). Since the absorption frequency range begins in the $\mathrm{C}$-band, the $\mathrm{ABW}$ is smaller than the previous one, reaching $2.09 \mathrm{GHz}$. However, it has potential to be bigger if the $\mathrm{C}$-band is considered. This arrangement helps to create a gradient material, where the impedance mismatch between free space, the second layer, and the first layer is gradually reduced. This results in a low-reflection in the air-material interface and allows attenuation of the signal in the next layer [29].

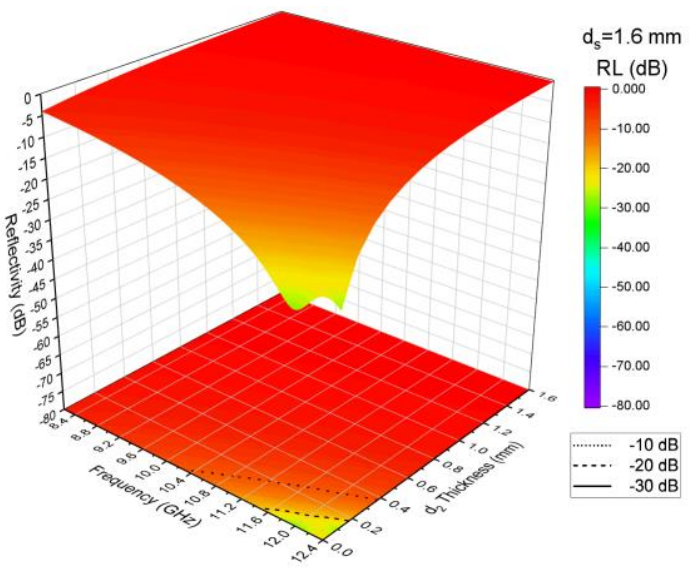

(a)

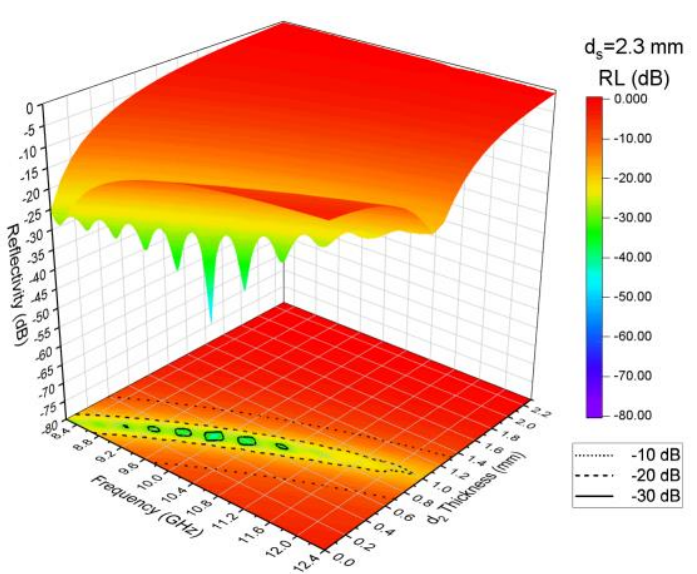

(c)

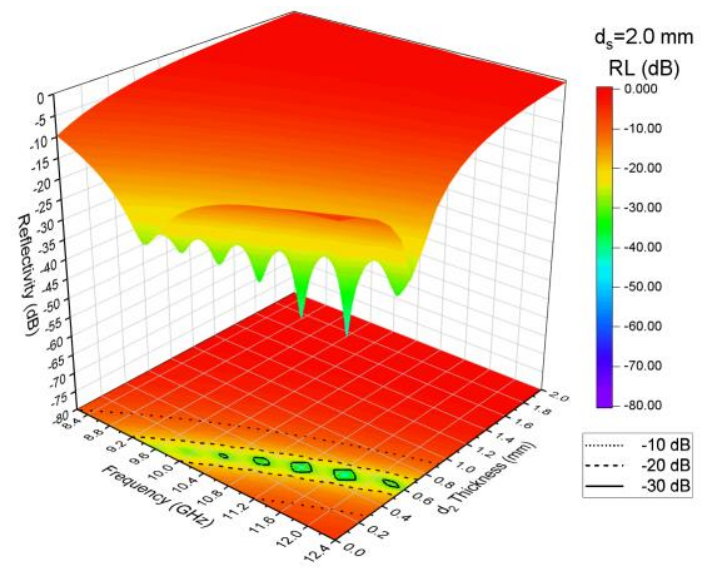

(b)

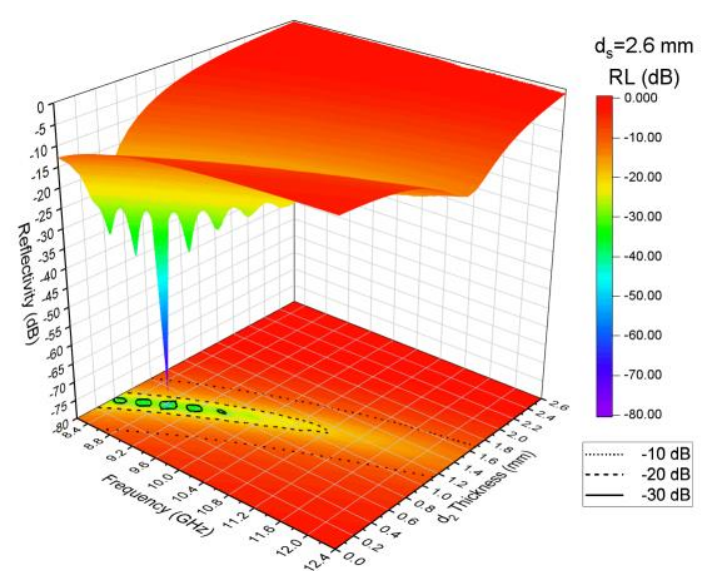

(d)

Figure 6: RL of multilayer system where the first layer is a ferrite-based composite and the second layer is the 4 wt.\% biochar composite. The total thicknesses of the double-layer structures are (a) $1.6 \mathrm{~mm}$ (b) $2.0 \mathrm{~mm}$, (c) $2.3 \mathrm{~mm}$ and (d) $2.6 \mathrm{~mm}$.

In summary, biochar composites may not work as a RAM in the X-band frequency range, but it certainly provides a sustainable alternative to improve the RL and ABW in double-layer structures, as presented in Table 2. Such structures also can work in other frequency bands since their bandwidths reach the $\mathrm{C}$ and $\mathrm{K}_{\mathrm{u}}$ bands. Moreover, by controlling each layer thickness, it is possible to tune the RL in any frequency, which is a desirable characteristic when designing new materials for novel applications. Finally, such structures can be employed on radomes, electromagnetic shielding and sensors applications. 
Table 2: Summarized information about the best RL and ABW in the X-band frequency range for ferrite-based composites and double-layer structures.

\begin{tabular}{|c|c|c|c|c|c|c|c|}
\hline DESCRIPTION & $\begin{array}{l}\mathrm{d} \text { OR } \mathrm{d}_{\mathrm{S}} \\
(\mathrm{mm})\end{array}$ & $\begin{array}{l}\mathrm{d}_{1} \\
(\mathrm{~mm})\end{array}$ & $\begin{array}{l}\mathrm{d}_{2} \\
(\mathrm{~mm})\end{array}$ & $\begin{array}{l}\text { RL } \\
(\mathrm{dB})\end{array}$ & $\begin{array}{l}\text { RL } \\
\text { FREQUENCY } \\
(\mathrm{GHz})\end{array}$ & $\begin{array}{lr}\text { ABSORPTION } & \text { FRE- } \\
\text { QUENCY } & \text { RANGE } \\
(\mathrm{GHz}) & \end{array}$ & $\begin{array}{l}\mathrm{ABW} \\
(\mathrm{GHz})\end{array}$ \\
\hline \multirow{4}{*}{$\begin{array}{l}\text { Ferrite-based } \\
\text { composite }\end{array}$} & 1.6 & - & - & -28.08 & 11.98 & from 10.31 to $\mathrm{K}_{\mathrm{u}}$-band & 2.09 \\
\hline & 2.0 & - & - & -28.08 & 9.59 & from 8.24 to 11.16 & 2.92 \\
\hline & 2.3 & - & - & -28.08 & 8.33 & from C-band to 9.71 & 1.51 \\
\hline & 2.6 & - & - & -12.79 & 8.2 & from C-band to 8.59 & 0.39 \\
\hline \multirow{4}{*}{$\begin{array}{l}\text { Biochar as Lay- } \\
\text { er } 1 \text { and Ferrite } \\
\text { as Layer } 2\end{array}$} & 1.6 & 0.2 & 1.4 & -39.09 & 12.32 & from 10.68 to $\mathrm{K}_{\mathrm{u}}$-band & 1.72 \\
\hline & 2.0 & 0.2 & 1.8 & -59.89 & 9.80 & from 8.47 to 11.34 & 2.87 \\
\hline & 2.3 & 0.2 & 2.1 & -57.09 & 8.49 & from C-band to 9.84 & 1.64 \\
\hline & 2.6 & 0.8 & 1.8 & -17.92 & 8.20 & from C-band to 8.98 & 0.58 \\
\hline \multirow{4}{*}{$\begin{array}{l}\text { Ferrite as Layer } \\
1 \text { and Biochar } \\
\text { as Layer } 2\end{array}$} & 1.6 & 1.5 & 0.1 & -27.62 & 12.40 & from 10.80 to $\mathrm{K}_{\mathrm{u}}$-band & 1.60 \\
\hline & 2.0 & 1.5 & 0.5 & -44.93 & 11.68 & from 10.09 to $\mathrm{K}_{\mathrm{u}}$-band & 2.31 \\
\hline & 2.3 & 1.8 & 0.5 & -49.92 & 9.89 & from 8.53 to 11.48 & 2.95 \\
\hline & 2.6 & 2.0 & 0.6 & -76.56 & 8.85 & from C-band to 10.29 & 2.09 \\
\hline
\end{tabular}

The investigation of sustainable carbon as radar absorbing material is still a rising topic. This is the first time that a sustainable porous carbon is considered as a multilayer structure to the best of our knowledge. In this sense, Table 3 compares of the results presented here with the results of multilayer structures that use regular fillers, like NiZn ferrite, SiC, and several structures of carbon material like carbon black, carbon nanotube, and graphene. Theoretically, a thin double-layer structure with biochar can achieve reflectivity as good as a three-layer structure using hexaferrite, and an absorption bandwidth comparable to a three-layer structure using carbon materials.

Table 3: Comparison of reflectivity and absorption bandwidth between biochar/ferrite-based composite and other multilayer structures reported in the literature.

\begin{tabular}{|c|c|c|c|c|c|}
\hline FILLERS & $\begin{array}{l}\text { STRUCTURE } \\
\text { THICKNESS } \\
(\mathrm{mm}) \\
\end{array}$ & $\begin{array}{l}\text { NUMBER OF } \\
\text { LAYERS }\end{array}$ & $\begin{array}{l}\text { REFLECTIVITY } \\
(\mathrm{dB})\end{array}$ & $\begin{array}{l}\text { ABSORPTION } \\
\text { BANDWIDTH } \\
(\mathrm{GHz}) \\
\end{array}$ & REFS. \\
\hline \multirow{3}{*}{ 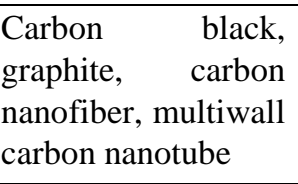 } & 2.60 & 2 & -25.18 & 4.48 & \multirow[t]{3}{*}[30]{} \\
\hline & 2.60 & 3 & -44.97 & 2.99 & \\
\hline & 4.70 & 4 & -28.50 & 6.40 & \\
\hline $\mathrm{SiC}, \mathrm{Si3N} 4, \mathrm{SiBCN}$ & 16.00 & 3 & -15.00 & 4.20 & [31] \\
\hline \multirow{3}{*}{$\begin{array}{l}\text { U-type hexaferrite: } \\
\mathrm{Ba}_{4}\left(\mathrm{Co}_{1-}\right. \\
\left.{ }_{3 \mathrm{x}} \mathrm{Cr}_{\mathrm{x}}\right) \mathrm{Fe}_{36} \mathrm{O}_{60}, \\
\mathrm{x}=0.05, \quad 0.1, \quad 0.2, \\
\text { and } 0.25\end{array}$} & 1.76 & 2 & -68.00 & 3.86 & \multirow[t]{3}{*}[32]{} \\
\hline & 1.76 & 3 & -79.17 & 3.86 & \\
\hline & 1.80 & 4 & -80.94 & 3.95 & \\
\hline $\begin{array}{l}\mathrm{Ni} \text { ferrite, } \mathrm{NiZn} \\
\text { ferrite }\end{array}$ & 1.72 & 2 & -45.00 & 3.30 & [33] \\
\hline \multirow{2}{*}{$\begin{array}{l}\text { Biochar, NiZn fer- } \\
\text { rite }\end{array}$} & 2.6 & 2 & -76.56 & 2.09 & \multirow{2}{*}{$\begin{array}{l}\text { This } \\
\text { work }\end{array}$} \\
\hline & 2.3 & 2 & -49.92 & 2.95 & \\
\hline
\end{tabular}

\section{CONCLUSIONS}

It is detailed here how a sustainable porous carbon material improves the reflection loss and the absorption 
bandwidth of a double-layer structure with a ferrite-based composite. Although composites made with biochar did not present a significant RL, they can develop tunable multilayer structures. A double-layer structure of $2.6 \mathrm{~mm}$ presented a RL of $-76.56 \mathrm{~dB}$. The wider absorption bandwidth calculated was for the structure with $2.3 \mathrm{~mm}$ thickness, where the $\mathrm{ABW}$ was $2.95 \mathrm{GHz}$ over the entire X-band frequency range. This versatility makes biochar a suitable alternative for designing a multilayer structure since it is a cheap material from renewable sources. Such structures may be used on electromagnetic shielding and others applications where an extremely efficient RL and a large absorption bandwidth are required.

\section{ACKNOWLEDGES}

A. F. N. Boss acknowledges CAPES-PNPD for funding his post-doctoral research. This study was also supported by Québec's Ministry of Economy, Science and Innovation (Ministère de l'Économie, de la Science et de l'Innovation du Québec), the Natural Sciences and Engineering Research Council of Canada (NSERC), the Canada Research Chair Program, Abitibi-Témiscamingue College, and the Technology Center for Industrial Waste (Centre Technologique des Résidus Industriels) through its partner on this project, Airex Energy. Dr. Flavia Lega Braghiroli sincerely acknowledges financial support by the NSERC via a Banting Postdoctoral Fellowship (2017-2019).

\section{BIBLIOGRAPHY}

[1] MENG, F., WANG, H., HUANG, F., GUO, Y., WANG, Z., HUI, D., ZHOU, Z., "Graphene-based microwave absorbing composites: A review and prospective", Composites Part B: Engineering, v. 137, pp. 260-277, Nov. 2018.

[2] YANG, R.B., HSU, S.D., LIN, C.K., "Frequency-dependent complex permittivity and permeability of iron-based powders in 2-18 GHz", Journal of Applied Physics, v. 105, n. 7, pp. 07A527-1-07A527-4, 2009.

[3] ZHANG, C.-F., TANG, W., MI, X.-L., CHEN, L.-R., "Application of radar absorbing material in design of metal space frame radomes", In: Proceedings of the Proceedings of 2011 Cross Strait Quad-Regional Radio Science and Wireless Technology Conference, pp. 222-225, Heilongjiang, 2011.

[4] CHUNG, D.D.L., "Materials for Electromagnetic Interference Shielding", Journal of Materials Engineering and Performance, v. 9, n. 3, pp. 350-354, 2000.

[5] KAUSAR, A.; RAFIQUE, I.; MUHAMMAD, B., "Review of Applications of Polymer/Carbon Nanotubes and Epoxy/CNT Composites", Polymer-Plastics Technology and Engineering, v. 55, n. 11, pp. 11671191, 2016.

[6] AHMAD, H., TARIQ, A., SHEHZAD, A., FAHEEM, M. S., SHAFIQ, M., RASHID, I. A., AFZAL, A., MUNIR, A., RIAZ, M. T., HAIDER, H. T., AFZAL, A., QADIR, M. B., KHALIQ, Z. "Stealth technology Methods and composite materials", Polymer Composites, v. 40, n. 12, pp. 4457-4472, 2019.

[7] LIMA, U. R., NASAR, M. C., NASAR, R. S., REZENDE, M. C., ARAÚJO, J. H. "Ni-Zn nanoferrite for radar-absorbing material", Journal of Magnetism and Magnetic Materials, v. 320, n. 10, pp. 1666-1670, 2008.

[8] FENG, Y.-B., QIU, T., SHEN, C.-Y., LI, X.-Y. "Electromagnetic and absorption properties of carbonyl iron/rubber radar absorbing materials," IEEE Transactions on Magnetics, v. 42, n. 3, pp. 363-368, 2006.

[9] SHEN, Z., CHEN, J., LI, B., LI, G., ZHANG, Z., HOU, X. "Recent progress in SiC nanowires as electromagnetic microwaves absorbing materials", Journal of Alloys and Compounds, v. 815, p. 152388, 2020.

[10] OH, J.-H., OH, K.-S, KIM, C.-G., HONG, A.-S. "Design of radar absorbing structures using glass/epoxy composite containing carbon black in X-band frequency ranges", Composites Part B: Engineering, v. 35, n. 1, pp. 49-56, 2004.

[11] BALCI, O., POLAT, E. O., KAKENOV, N., KOCABAS, C., "Graphene-enabled electrically switchable radar-absorbing surfaces", Nature Communications, v. 6, p. 6628, 2015.

[12] MUNIR, A. "Microwave radar absorbing properties of multiwalled carbon nanotubes polymer composites: A review", Advances in Polymer Technology, v. 36, n. 3, pp. 362-370, 2017.

[13] LIU, X., ZHANG, Z., WU, Y., "Absorption properties of carbon black/silicon carbide microwave absorbers", Composites Part B: Engineering, v. 42, n. 2, pp. 326-329, 2011.

[14] KHUSHNOOD, R.A., AHMAD, S., SAVI, P., TULLIANI, J.-M.M., GIORCELLI, M., FERRO, G.A., "Improvement in electromagnetic interference shielding effectiveness of cement composites using carbonaceous nano/micro inerts", Construction and Building Materials, v. 85, pp. 208-216, 2015. 
[15] BRAGHIROLI, F.L., BOUAFIF, H., HAMZA, N., BOUSLIMI, B., NECULITA, C.M., KOUBAA, A., "The influence of pilot-scale pyro-gasification and activation conditions on porosity development in activated biochars", Biomass and Bioenergy, v. 118, pp. 105-114, Feb. 2018.

[16] GIORCELLI, M., KHAN, A.A., TAGLIAFERRO, A., SAVI, P., BERRUTI, F., "Microwave characterization of polymer composite based on Biochar: A comparison of composite behaviour for Biochar and MWCNTs", In: Proceedings of the 2016 IEEE International Nanoelectronics Conference (INEC), pp. 1-2, Singapore, Oct. 2016.

[17] OK, Y.S., CHANG, S.X., GAO, B., CHUNG, H.-J., "SMART biochar technology-A shifting paradigm towards advanced materials and healthcare research", Environmental Technology \& Innovation, v. 4, pp. 206-209, 2015.

[18] World Commission on Environment and Development, Our Common Future, 1 ed., Oxford University Press, 1987.

[19] BRAGHIOLI, F.L., CUÑA, A., SILVA, E.L., AMARAL-LABAT, G., LENZ E SILVA, G.F.B., BOUAFIF, H., KOUBAA, A., "The conversion of wood residues, using pilot-scale technologies, into porous activated biochars for supercapacitors", Journal of Porous Materials, pp. 1-12, 2019.

[20] MA, C., HUANG, H., GAO, X., WANG, T., ZHU, Z., HUO, P., LIU, Y., YAN, Y., "Honeycomb tubular biochar from fargesia leaves as an effective adsorbent for tetracyclines pollutants", Journal of the Taiwan Institute of Chemical Engineers, v. 91, pp. 299-308, 2018.

[21] NICOLSON, A. M., ROSS, G. F., "Measurement of the Intrinsic Properties of Materials by TimeDomain Techniques", IEEE Transactions on Instrumentation and Measurement, v. 19, n. 4, pp. 377-382, 1970.

[22] LUUKKONEN, O., MASLOVSKI, S. I., TRETYAKOV, S. A., "A Stepwise Nicolson-Ross-WeirBased Material Parameter Extraction Method", IEEE Antennas and Wireless Propagation Letters, v. 10, pp. 1295-1298, 2011.

[23] WEN, F., HOU, H., XIANG, J., ZHANG, X., SU, Z., YUAN, S., LIU, Z., "Fabrication of carbon encapsulated Co $3 \mathrm{O} 4$ nanoparticles embedded in porous graphitic carbon nanosheets for microwave absorber", Carbon, v. 89, pp. 372-377, 2015.

[24] SOUZA PINTO, S., MACHADO, J. P. B., GOMES, N. A. S., REZENDE, M. C., "Electromagnetic, morphological and structural characterization of microwave absorbers based on POMA/magnetic filament composites", Journal of Magnetism and Magnetic Materials, v. 449, pp. 406-414, 2018.

[25] NAITO, Y., SUETAKE, K., "Application of Ferrite to Electromagnetic Wave Absorber and its Characteristics", IEEE Transactions on Microwave Theory and Techniques, v. 19, n. 1, pp. 65-72, 1971.

[26] MESHRAM, M. R., AGRAWAL, N. K., SINHA, B., MISRA, P. S., "Characterization of M-type barium hexagonal ferrite-based wide band microwave absorber", Journal of Magnetism and Magnetic Materials, v. 271, n. 2-3, pp. 207-214, 2004.

[27] PARK, K.-Y., HAN, J.-H., LEE, S.-B., KIM, J.-B., YI, J.-W., LEE, S.-K., "Fabrication and electromagnetic characteristics of microwave absorbers containing carbon nanofibers and magnetic metals", In: Proceedings of the Composites Science and Technology, v. 69, p. 69292G, San Diego, Mar. 2008.

[28] REINERT, J., PSILOPOULOS, J., GRUBERT, J., JACOB, A. F. "On the potential of graded-chiral Dallenbach absorbers", Microwave and Optical Technology Letters, v. 30, n. 4, pp. 254-257, 2001.

[29] SIVA NAGASREE, P., RAMJI, K., SUBRAMANYAM, C., KRUSHNAMURTHY, K., HARITHA, T. "Synthesis of $\mathrm{Ni}_{0.5} \mathrm{Zn}_{0.5} \mathrm{Fe}_{2} \mathrm{O}_{4}$-reinforced E-glass/epoxy nanocomposites for radar-absorbing structures", Plastic, Rubber and Composites, v. 49, 2020.

[30] KASGOZ, A., KORKMAZ, M., DURMUS, A. "Compositional and structural design of thermoplastic polyurethane/carbon based single and multi-layer composite sheets for high-performance X-band microwave absorbing applications", Polymer, v. 180, p. 121672, 2019.

[31] LI, M., CHENG, L., MO, R., YE, F., YIN, X. "(SiC-Si3N4)w/SiBCN composite ceramics with tunable electromagnetic properties", Journal of Alloys and Compounds, v. 798, pp. 280-289, 2019.

[32] PADHY, S., DE, A., DEBATA, R. R., MEENA, R. S. "Design, Characterization, and Optimization of a Multilayer U-type Hexaferrite-Based Broadband Microwave Absorber", IEEE Transactions on Electromagnetic Compatibility, v. 60, n. 6, pp. 1734-1742, 2018. 
[33] SMITHA, P., SINGH, I., NAJIM, M., PANWAR, R., SINGH, D., AGARWALA, V., VARMA, G. D. "Development of thin broad band radar absorbing materials using nanostructured spinel ferrites", Journal of Materials Science, v. 27, pp. 7731-7737, 2016.

\section{ORCID}

Alan Fernando Ney Boss

Helena Ravaglia Ferreira

Flavia Lega Braghiroli

Gisele Aparecida Amaral-Labat

Ariane Aparecida Teixeira de Souza

Hassine Bouafif

Ahmed Koubaa

Mauricio Ribeiro Baldan

Guilherme Frederico Bernardo Lenz e Silva https://orcid.org/0000-0002-4600-5443

https://orcid.org/0000-0001-9775-9061

https://orcid.org/0000-0001-7840-8311

https://orcid.org/0000-0003-3745-6119

https://orcid.org/0000-0002-5893-2885

https://orcid.org/0000-0002-2831-0743

https://orcid.org/0000-0002-7895-1901

https://orcid.org/0000-0001-7605-1064

https://orcid.org/0000-0003-1184-5271 